DOI: 10.20472/IAC.2019.049.001

\title{
LÍVIA ABLONCZY-MIHÁLYKA
}

Széchenyi István University of Győr, Hungary

\section{CHALLENGES IN HIGHER EDUCATION CASE: BACHELOR COURSE IN INTERNATIONAL RELATIONS}

\begin{abstract}
:
Universities have always faced a number of challenges at the international, national and institutional levels and have always had to develop new strategies to overcome the difficulties. Recently internationalisation of universities is a key factor and, as evidence of the Széchenyi University's strong commitment to internationalisation, from September 2019, twenty-four English-taught programmes at all academic levels are on offer.

One of the courses is BA in International Relations. The undergraduate programme in International Relations is for individuals who are sensitive to global problems, open to other cultures, and are prepared to handle a broad range of evidence and analyse complex issues. It is a multidisciplinary programme which combines a wide range of courses in international relations, history, economics, political science, foreign languages, sociology and regional studies, among other disciplines. The programme trains the students to be well informed about generally accepted tendencies, characteristics and data on universal political, economic and cultural phenomena. They will thus have deeper insights into and understanding of relations of various nations and cultures.
\end{abstract}

The purpose of this paper is (1) to describe the research conducted prior to the course development process, e.g. analysis of the new national requirements for the International Relations BA course, the curricula at international and national levels and the findings of a questionnaire-based research conducted among the former students at International Relations BA course. After presenting the preparatory process (2) the programme will be examined and discussed focusing on the aim and the content of the course, the structure of studies, the academic and language requirements.

\section{Keywords:}

Internationalisation of Higher Education, International Relations, BA Course, Students' Opinion, Recommendations

JEL Classification: 123,121 


\section{Introduction ${ }^{1}$}

Universities worldwide have come under increasing pressures to adapt to rapidly changing social, technological and economic forces emanating from the external environment (Bartell 2003). Higher education institutions have to respond to the changing situation requiring significant transformation in the institutional strategy that comprises two important key factors: internationalisation and practice-oriented education.

It is accepted that internationalisation has become a key strategic element of universities across the world and the institutions have to integrate it into their broad strategic choices (Maringe 2009). In the past decade numerous articles have been published on the internationalisation in higher education (see for example: Elkin et al. 2005, Altbach et al. 2009, Konczosné et al. 2016, Tompos et al. 2016, Szőke et al. 2017 , etc.) analysing whether universities have effective international programmes, courses and/or policies in response to increasing demand.

One of the effects of pedagogical evolution is that the education paradigm has shifted over the years and this created a different set of values (Mason 1998). Recently there has been movement towards digitalisation, interactivity in the learning process, the team-working and the practice-oriented education, e.g. courses required by the labour market.

This paper aims to cover an English-taught programme at Széchenyi University of Győr, the International Relations BA course. First, the research conducted prior to the course development process will be described. Then the programme will be examined and discussed focusing on the aim and the content of the course, the structure of studies, the academic and language requirements.

\section{Background to the study}

At present every aspect of our social, scientific and mental life is subjected to accelerate development and universities face a number of challenges at the international, national and institutional levels and have to develop new strategies to overcome the difficulties. Universities have to take actions soon: programmes in higher education have to be (re)structured and new types of study programmes (in contents and methods) have to be developed. One of the priorities is practice-oriented education, which is a term that provokes strong reactions, positive or negative by academics but practice-oriented education is praised for the new opportunities it brings.

Higher education institutions have to be transformed to take up challenges for sustainable development. Majumdar (2019) classified the demands and came to the conclusion that

- it is time to initiate bottom up innovation in higher education: it is not about degrees but about competences

\footnotetext{
1 The author of the paper would like to thank EFOP-3.6.1-16-2016-00017 project titled Internationalization, initiatives to establish a new source of researchers and graduates, and development of knowledge and technological transfer as instruments of intelligent specializations at Szechenyi University for supporting this research.
} 
- adaptability and flexibility are key-terms

- action plans are needed for continuous improvement

- active engagement is required with industry, (national and local) communities, and institutes of higher learning

- innovative teaching techniques and innovative course materials are a must.

In May 2019 the $29^{\text {th }}$ EURASHE ${ }^{2}$ conference was organised in Budapest (with the title: Future students. Future universities. Future jobs.) where all the speakers highlighted the importance of practice-oriented education, the need of dialogue between universities and the labour market, the collaboration between university groups and the society and the must for reformulating all the curricula at bachelor and master levels. At the conference Wagenaar (2019) highlighted the importance of integrating entrepreneurship and work experience in higher education and as an example he presented one of his projects, titled WEXHE, where associations and universities come together to identify and analyse current provision of work experience in higher education in 7 different European countries. He outlines that the employers have increasing difficulties in finding graduates with matching skills and capabilities for 'knowledge age' jobs and what kind of practice-based learning leads to high quality jobs.

Lauwick, the president of EURASHE, addressed the future of education and emphasised that "the world, our New World, needs new education systems. Systems that enable every European citizen to find their way, invent their own learning pathways, define their own goals, in short, construct their own personal excellence. Clearly this is not happening now, or it is not happening fast enough. Our structures are too rigid, we think in silos; the skills mismatch is still the same as it was 20 years ago" (2019).

Széchenyi University has also recognised that the education has to be restructured because it is required by the labour market as well as by the students whose motivation has been changed. Széchenyi University is considered an entrepreneurial university, i.e. a new generation of higher education institution (Rámháp et al. 2017). Recently practice-oriented education has been in focus and new types of study programmes have been developed.

\section{International Relations BA course}

\section{Preparatory process}

Prior to the course development process a research has been conducted, e.g. analysis of the new national requirements for the International Relations BA course, the curricula at international and national levels and the findings of a questionnairebased research conducted among the former students at International Relations BA course.

The key question remains: our social and economic environment is changing in ways no-one can anticipate. Changes happen without teachers but they have to be able to

\footnotetext{
${ }^{2}$ European Association of Institutions in Higher Education
} 
prepare students and train them according to the 'new' world. Employers have increasingly been demanding practice-oriented education, transferable skills of students, the ability to work in a team, creative thinking and problem solving.

Analysing the findings of the research it was revealed that

- there is a strong demand by former students for a new set of skills (creative, critical and innovative thinking, communication skills development, etc.)

- more practice-oriented subjects, less theory (applying theoretical learnings to real projects)

- reinforcement collaboration skills is a must

- development of partnerships and finding professional mentors

- new curricula is needed: making students more active in the acquisition of knowledge and skills.

The main findings of the research demonstrate that the terms creativity, communications skills development and practical-based courses are relatively frequently mentioned by students and employers as well.

\section{International Relation BA course: vision, mission and content}

International Relations is a sub-discipline in the field of Social Sciences. It connects to numerous other subjects, including Politics, History, Linguistics, Economics, Philosophy, Religious Studies, Business, and Law. People involved in International Relations analyse global problems, such as poverty, human rights, ethics, and try to find solutions based on interdisciplinary research.

The International Relations BA course aims to educate professionals who understand international relations, can represent national and regional interests, are sensitive to global problems and open to other cultures; if relevant, they can meet the challenges of the EU integration process. Graduate students, as employees of national and international companies, governmental or non-governmental organisations, are able to deal with international contacts, can creatively and flexibly solve problems and complex tasks as well as step up to master-level education.

As for the competences, International relations experts

- are well-informed about the generally accepted tendencies, characteristics and data of Hungarian and universal political, economic and cultural phenomena

- can interpret specialist area-related and interconnected international, European and regional political, legal, economic and cultural issues and events in their proper context

- are aware of the forms, tools and techniques of international contact

- know the operation, scope of authority and policies of the institutions of the European Union

- are able to acquire and systematise historical, social, economic, legal and political knowledge

- can read specialist literature and understand specialist terminology in at least two foreign languages

- are able to interpret international relations-related phenomena from the point of view of at least one non-European culture or ideology 
- can carry out project-based tasks

- can produce written analyses on their own, as well as present their accomplished tasks to a professional audience both orally and in writing

- are able to critically analyse and process information.

The Table 1 shows the content of the programme and the ratio of knowledge areas.

TABLE 1. International Relations BA course - knowledge areas ${ }^{3}$

\begin{tabular}{|c|c|c|}
\hline Knowledge areas & ECTS & $\%$ \\
\hline $\begin{array}{l}\text { 1. General social sciences-related } \\
\text { knowledge and competencies }\end{array}$ & 24 & 13,3 \\
\hline $\begin{array}{l}\text { 2. Methodological knowledge and skills } \\
\text { development }\end{array}$ & 27 & 15 \\
\hline 3. Professional knowledge (core material) & 89 & 49,4 \\
\hline $\begin{array}{l}\text { 4. Compulsory and optional elective } \\
\text { subjects }\end{array}$ & 30 & 16,7 \\
\hline Thesis & 10 & 5,6 \\
\hline ECTS Total & 180 & 100 \\
\hline
\end{tabular}

Area 1: Philosophy, Politology, Sociology, Business IT Tools ${ }^{4}$, Economics, Basics of Law, Modern History

Area 2: Communication Practice /Foreign Language I., Communication Practice /Foreign Language II., Theory and Practice of Communication, Statistics, Research Methods of Social Sciences, Study Skills

Area 3. History of International Relations (1815-1945), Theory of International Politics, International Relations after 1945, Theory and Practice of Diplomacy, Fundamentals of International Law, Law of International Economic Relations, International Organizations and Institutions, Global Economy, Foreign Economic Policy, International Finance, Regional Studies, Intercultural Communication, Intercultural Communication /Foreign Language III., Negotiation Techniques, Negotiation Techniques /Foreign Language IV., History of EU, Academic Writing, International Protocol and Etiquette, Organization of International Events, Project Management, EU Law, Current Conflicts in the World

Area 4.

- Compulsory Elective Courses 1. ${ }^{5}$ (Social Sciences Module): Central-European Studies, Asia Studies, America Studies, Africa Studies

- Compulsory Elective Courses II. ${ }^{6}$ (Skills Development module): Presentation Skills Development, Management Communication, EU Documents, Manager Competences

\footnotetext{
${ }^{3}$ See in details: admissions.sze.hu

${ }^{4}$ Subjects in bold are practice-oriented.

${ }^{5}$ From the list two courses have to be chosen.

${ }^{6}$ From the list two courses have to be chosen.
} 
- Freely Elected Courses: Short Story Time, Comparative Country Studies, Geography, Law of Diplomacy, Parliaments in Central-Eastern Europe, Gender Studies, Global Environmental Challenges, Matters of Nationality in International Law

As for the thesis: it elaborates on a theoretical or practical specialist area-related problem, relying either exclusively on secondary sources or on primary research. Through the thesis, the candidates prove that they can apply the knowledge gained during their studies and also that they are able to consult specialist literature on their own. The thesis is to be written in one semester with the guidance of a supervisor.

The accomplishment of the curricular requirements, inclusive of

- at least 180 ECTS, of which the thesis is worth of 10 ECTS;

- work placement,

- physical education,

- a thesis accepted by the supervisor and a reader.

The final exam consists of

- a complex oral professional examination, where the candidates are required to prove their ability to synthetize their knowledge gained in different areas and in a wide range of topics

- the defence of the thesis.

\section{Conclusion}

The world is changing and changing the way we teach and learn. The role and the tasks of higher education institutions are changing in the world and every university has to re-think the strategies to be able to attract many students as they could. Not only in Hungary but worldwide there is a competition for students and professors and universities have to face demands required by the labour market. Practice-oriented education is one of the priorities and Széchenyi University of Györ provides courses in English to attract more foreign and national students.

One of the courses is BA in International Relations, a programme that trains the students to be well informed about generally accepted tendencies, characteristics and data on universal political, economic and cultural phenomena. The undergraduate programme is for individuals who look for a BA course that provides to become an actor at a global level, who want to become a member of the country's Foreign service or a consultant for a multilateral organisation or an executive in a multinational corporation or a development expert in an NGO.

The International Relations BA course prepares students for leadership and service in the international diplomatic, professional, and academic communities. The students have deeper insights into and understanding of relations of various nations and cultures. In a globalizing world, the study of international relations provides a portal for entry into a variety of career fields. 


\section{Reference}

ALTBACH, P.G., REISBERG, L., RUMBLEY, L. E. 2009. Trends in Global Higher Education. A report prepared for the UNESCO 2009 World Conference on Higher Education. Paris: UN Educational, Scientific and Cultural Organisation

BARTELL, M. 2003. Internationalization of universities: A university culture-based framework. Higher Education 45. 43-70.

ELKIN, G., DEVJEE, F., FARNSWORTH, J. 2005. Visualising the "internationalisation" of universities. International Journal of Educational Management, 19(4). 318-329. https://doi.org/10.1108/09513540510599644

KONCZOSNÉ SZOMBATHELYI, M., HEANEY, J., RYAN, P. 2016. A comparison of higher education in Hungary and Australia. In: Ogunnokun, G. - Gabbay, R. - Rose, J. (eds.) Managing, Marketing and Financing Organizations in an Era of Economic Uncertainty. Budapest: Academy of World Business, Marketing and Management Development. 336-350.

LAUWICK, S. 2019. The future of education A paper presented at the $29^{\text {th }}$ EURASHE Annual Conference, Future Students, Future Universities. Future Jobs. Professional Higher Education in the Changing World. Budapest University of Technology and Economics. 15-17 May 2019.

MAJUMDAR, S. 2019. The major trends impacting future of jobs. A paper presented at the $29^{\text {th }}$ EURASHE Annual Conference, Future Students, Future Universities. Future Jobs. Professional Higher Education in the Changing World. Budapest University of Technology and economics. 15-17 May 2019.

MARINGE, F. 2009. Strategies and challenges of internationalisation in HE: An exploratory study of UK universities, International Journal of Educational Management, 23(7), 553-563. https://doi.org/10.1108/09513540910990799.

MASON, R. 1998. Models of online courses. A paper presented at Networked Lifelong Learning: Innovative Approached to Education and Training through the Internet Conference, University of Sheffield, Sheffield, UK, April 20-22. 172-179.

RÁMHÁP, Sz., NAGY, D., ORSZÁGH, Á., RECHNITZER, J., FILEP, B. 2017. Carrier choice motivation of high school students in context with changing higher education in knowledge economy. Poslovna Izvrsmost / Business Excellence. 11(2), 23-37.

SZÖKE, J., TOMPOS, A., ABLONCZYNÉ MIHÁLYKA, L. 2017. Internationalisation and intercultural competence in the context of tertiary education. In: Štefančík, R., - Kapil, R. (eds.) Cudzie jazyky v premenách času VII. / Foreign Languages in Changing Times VII. Recenzovanỳ zborník prívspevkov z mezdinárodnej vedeckej konferencie / Reviewed Conference Proceedings from an International Scientific Conference. Bratislava: Vydavatelstvo Ekonóm, 123-127.

TOMPOS, A., SZÖKE, J. ABLONCZYNÉ MIHÁLYKA, L. 2016. Nemzetköziesítés: hallgatói tapasztalatok az Erasmus mobilitás kapcsán. In: Reisinger A., Kecskés P. (szerk.) "Ifjúság - jövőképek": Kautz Gyula Emlékkonferencia 2016. június 15. elektronikus formában megjelenő kötete. Győr: Széchenyi István Egyetem. https://kgk.sze.hu/images/dokumentumok/kautzkiadvany2016/TomposA_SzokeJ_Ablo nczyneML.pdf (Last access: 12 May 2019) 
WAGENAAR, R. 2019. Integrating entrepreneurship and work experience in higher education. A paper presented at the $29^{\text {th }}$ EURASHE Annual Conference, Future Students, Future Universities. Future Jobs. Professional Higher Education in the Changing World. Budapest: University of Technology and Economics. 15-17 May 2019. 